\title{
A study on relationship between inflation rate and changes in profitability ratios in Tehran Stock Exchange
}

\author{
Mohammad Ali Aghaee ${ }^{a^{*}}$ and Morteza Kazempour ${ }^{b}$
}

${ }^{a}$ Department of Management and Economics, Tarbiat Modares University(TMU), Tehran, Iran ${ }^{b}$ MSc student of accounting, Department of Management and Economics, Tarbiat Modares University(TMU), Tehran, Iran

C H R O N I C L E

\section{Article history:}

Received June 22, 2013

Received in revised format

28 August 2013

Accepted 27 September 2013

Available online

September 292013

Keywords:

Inflation rate

Return on equity

Return on assets

Net profit ratio

Gross profit ratio

\section{A B S T R A C T}

\begin{abstract}
In this paper, we examine the relationship between inflation rate and profitability ratios in the top 36 companies in the Tehran Stock Exchange (TSE). The study uses historical data over the period 2005-2010 and using linear regression methods examines different hypotheses. The main idea of the proposed hypotheses is that there is a significant relationship between the inflation rate and profitability ratios, and the results confirm the significant relationship between the inflation rate and profitability ratios such as return on assets (ROA) ratio, return on equity (ROE) ratio, gross profit (GPR) as well as net profit ratio (NPR). There is no significant correlation, however, between these two variables in past and future periods.
\end{abstract}

(C) 2013 Growing Science Ltd. All rights reserved.

\section{Introduction}

One of the primary concerns on any economy is to study the effect of inflation on performance of stock exchange and Fisher (1930) first introduced this idea and called it Fisher Effect for explaining the relationship between return on assets and inflation. For a period of forty years, from 1930 to 1970, the Fisher Effect remained the logical explanation for the equity-inflation relationship as it reinforced the doctrine that an asset's underlying value could be retained in the presence of inflation. Ely and Robinson (1997) applied data extracted from 16 industrialized economies to test the nature of this relationship and found that stock market prices maintain their values in the face of inflation.

Boudoukh and Richardson (1993) examined the relationship between stock returns and inflation in the United States and the United Kingdom in the short-term horizon (one year) and in the long term (five years). They concluded that with a term of one year or less inflation and stock returns are negatively related. However, the five-year horizon is positively associated with stock returns and *Corresponding author. Tel: +989124338858

E-mail address: aghaeim@modares.ac.ir (M. A. Aghaee) 
inflation. In this study, we study the effect of inflation on profitability ratios to examine the five-year horizon. We have chosen this term, because a term of over five years creates a temporal overlap between the data, and the results obtained by standard methods are unreliable. The dependent variable in this study is the stock return in the Tehran Stock Exchange. However, to achieve a more favorable outcome as a replacement for stock returns, profitability ratios needs to be considered as an indicator and the independent variable in this study is the inflation rate.

The primary objective of this study is to discover whether or not the independent variable (inflation) and the dependent variable, return on equity in the Tehran Stock Exchange, are related. Seeking to explain the issue to decide on financial and accounting, organizations is faced with inflationary consequences. The primary question of this survey is whether it is possible to remove the effects of inflation to provide a greater certainty for investors or not and whether profitability is a good hedge against inflation or not.

\section{Literature review}

Boucher (2004) considered a new perspective on the relationship between stock prices, inflation by estimating the common long-term trends in real stock prices as reflected in the earning-price ratio, and both expected and realized inflation. He studied the role of transitory deviations from the common trend in the earning-price ratio and existing inflation in predicting stock market fluctuations. In particular, he reported that these deviations exhibit substantial in-sample and outof-sample forecasting abilities for both real stock and excess returns. Moreover, he reported that this variable incorporates information about future stock returns on short and intermediate horizons that is not captured by other popular forecasting variables. Choudhry (1998) investigated a positive relationship between stock market returns and inflation rate in four high inflation countries including Argentina, Chile, Mexico and Venezuela and concluded that the stock returns act as a hedge against inflation. Spyrou (2001) examined the relationship between stock returns and inflation rate in Greek by using monthly data from January 1990 to June 2000. The results for the period 1995-2000 demonstrated a negative but insignificant relationship, while for the period1990-1995 there was a significantly negative relationship.

Anari and Kolari (2001) used stock prices and goods prices instead of the first difference in order to overcome the problem that the first difference eliminates the long-run information. They used monthly stock price indices and goods price indices for Canada, France, Germany, the United Kingdom and the United States over the period 1953-1998. They employed the co-integration technique developed by Johansen (1988) for the goods prices and stock prices where they discovered that they were co-integrated and stationary at level data, confirming the long memory Fisher effect. However, they reported a negative initial effect for all six countries. Luintel and Paudyal (2006) supported previous results and reported the existence of the long-run hedging relationship in the UK stock market.

Al-Rjoub (2005) extended the empirical evidence by analyzing the reaction of monthly stock returns to the unexpected portion of CPI inflation rate and by capturing the asymmetric shocks to volatility of unexpected inflation in five MENA countries. Both threshold GARCH and exponential GARCH were applied to catch the news effects that unexpected inflation could have on stock returns. The results suggested a negative and strongly significant relationship between unexpected inflation and stock returns in MENA countries and also indicated that the stock markets of the listed MENA countries could not feel the high up's and down's movements in the markets and as such the volatilities and the asymmetric news effect was absent.

Chao Wei (2010) used VAR results to advocate inflation illusion as the explanation for the positive association between inflation and the dividend yield. Rango and Bayero (2010) studied volatility of stock returns and the effect of the applied generalized inflation. They reported that 
the volatility for Nigeria's markets were significant but insignificant for the market Ghana. Market volatility was influenced by inflation in both of the countries. An increase in market volatility but it was insignificant for the market of Ghana.

Ray (2012) attempted to examine the relationship between the inflation rate and stock prices of selected Asian countries, including India, Hong Kong, Japan, Korea, and Singapore over the period, 2002-2010. His conclusions indicated that, except in the case of Korea, correlations between inflation and stock prices were positive in most of the cases in his investigation. Stocks are a perfect hedge in the case of Hong Kong, India, Japan, and Singapore to the degree that corporate cash flow was positively associated with inflation following conventional Fisherian wisdom. In the case of Korea, however, stock prices were negatively associated with inflation, indicating that stock prices are not a good hedge against inflation. In conclusion, in countries like Hong Kong and Singapore, a long-run relationship existed between inflation rate and stock prices, but in the short run causality disappears. In the case of India and Korea, on the other hand, the short run unidirectional Granger causality running from inflation to stock prices was detected, but in the long run, the co-integrating relationship disappears.

Nwakanma and Ajibola (2013) examined the relationship between inflationary rates and returns on equity using the UVAR mechanism. The results obtained provide evidence to support the assertion that there is inconsistency in the nature of the relationship between inflation and returns on equity in Nigeria. Their findings further showed that the rates of inflation and returns on equity was increasing over time, but inflation rates rise faster than returns on equity. In fact, the margin was reported to be significant and detrimental to economic growth in Nigeria. Finally, they reported that there was no causal effect between previous inflationary rates and previous returns. This means that past rates of inflation did not Granger-cause past returns. However, a unidirectional effect was evident between current inflation and return at lag one with the direction of flow trickling down from inflation. Thus, current inflation does Granger cause immediate past return on equity in Nigeria.

Faiza et al. (2013) the objective of this study is to investigate the long-run relationship between the KSE 100 index return and inflation rates in Pakistan's economy. The evidence from the cointegration test indicated a negative relationship between the KSE 100 index return and the inflation rate, because Pakistan is an underdeveloped country. When inflation happens, it badly influences the economy, and this will ultimately influence stock returns. Reasons include the economic conditions and a budget deficit along with other factors. The Granger causality tests showed that there is no causality between KSE 100 index return and inflation rate in any direction.

\section{Hypothesis}

$\mathrm{H}_{1}$ : There is significant relationship between inflation and net income.

$\mathrm{H}_{2}$ : There is significant relationship between inflation and the gross profit.

$\mathrm{H}_{3}$ : There is a significant relationship between inflation and asset returns.

$\mathrm{H}_{4}$ : There is a significant relationship between inflation and the return on equity.

\section{Methodology}

This study is an applied research. To measure the degree of intensity of the relationship between two or more variables, we used multivariate correlation. We have used linear regression analysis to reach conclusions and respond to the hypotheses. We checked every single variable with the t-student test and reviewed them by using an $\mathrm{F}$ component in regression.

\subsection{Statistical population and sample selection}


The statistical population of this research included firms accepted and operating in the Tehran Stock Exchange (TSE) over the period 2005-2010. The data was collected from the TSE database available at the company library of the Tehran Stock Exchange. Data may also be downloaded from www.irbourse.com, or it can be purchased on CD. The research sample was the top 36 companies in the Tehran Stock Exchange, which were selected based on TSE criteria, including criteria such as the number and value of shares traded, number of trading days, the average market value, etc.

\subsection{Definition of variables}

\subsubsection{Independent variable}

Inflation (I) : In economics, inflation is a rise in the general level of prices of goods and services in an economy over a period of time. The inflation rate is widely calculated by calculating the movement or change in a price index, usually the consumer price index. The consumer price index measures movements in prices of a fixed basket of goods and services purchased by a "typical consumer". The inflation rate is the percentage rate of change of a price index over time. The Retail Prices Index is also a measure of inflation that is commonly used in the United Kingdom. It is broader than the CPI and contains a larger basket of goods and services.

\subsubsection{Depended variables}

Return on equity (ROE): measures the rate of return on the ownership interest (shareholders' equity) of the common stock owners. It measures a firm's efficiency at generating profits from every unit of shareholders' equity (also known as net assets or assets minus liabilities).

Return on assets (ROA): The return on assets (ROA) percentage shows how profitable a company's assets are in generating revenue. This number tells you what the company can do with what it has, i.e. how many dollars of earnings they derive from each dollar of assets they control. It's a useful number for comparing competing companies in the same industry. The number will vary widely across different industries. Return on assets gives an indication of the capital intensity of the company, which will depend on the industry; companies that require large initial investments will generally have lower return on assets.

NPR: Profit margin, net margin, net profit margin or net profit ratio all refer to a measure of profitability. It is calculated by finding the net profit as a percentage of the revenue. The profit margin is mostly used for internal comparison. It is difficult to accurately compare the net profit ratio for different entities. Individual businesses' operating and financing arrangements vary so much that different entities are bound to have different levels of expenditure, so that comparison of one with another can have little meaning. A low profit margin indicates a low margin of safety: higher risk that a decline in sales will erase profits and result in a net loss, or a negative margin.

GPR: Gross profit ratio is calculated by dividing gross profit on sales and used to evaluate operations and income.

\section{Results of hypotheses tests}

\subsection{Results of $H_{1}$ test}

We first present details of our findings on testing the first hypothesis of the survey, which is associated with relationship between net profit and interest rate. Table 1 and Table 2 show the summary of regression analysis as well as ANOVA results and Table 3 presents details of regression coefficients. 
Table 1

Model Summary

\begin{tabular}{ccccc}
\hline Model & $\mathrm{R}$ & $\mathrm{R}$ Square & Adjusted R Square & Std. Error of the Estimate \\
\hline 1 & $.240 \mathrm{a}$ & .058 & .057 & 1659.34056 \\
\hline a. predictors: (constant), inflation & & &
\end{tabular}

Table 2

The result of ANOVA ${ }^{\mathrm{b}}$ test

\begin{tabular}{ccccccc}
\hline Model & & Sum of Squares & df & Mean Square & F & Sig. \\
\hline 1 & Regression & 179388.000 & 1 & 179388.000 & 65.137 & $.000 \mathrm{a}$ \\
& Residual & 293889.000 & 1067 & 411079.275 & & \\
& Total & 983117.000 & 1068 & & & \\
\hline
\end{tabular}

a. Predictors: (Constant), inflation

b. Dependent Variable: NPR

\section{Table 3}

The results of regression analysis (Dependent variable $=$ NPR)

\begin{tabular}{|c|c|c|c|c|c|c|}
\hline \multirow{3}{*}{\multicolumn{2}{|c|}{ Model }} & \multicolumn{5}{|c|}{ Standardized } \\
\hline & & \multicolumn{2}{|c|}{ Unstandardized Coefficients } & Coefficients & \multirow[b]{2}{*}{$\mathrm{t}$} & \multirow[b]{2}{*}{ Sig. } \\
\hline & & $\mathrm{B}$ & Std. Error & Beta & & \\
\hline \multirow[t]{2}{*}{1} & (Constant) & -1700.368 & 214257.000 & & -7.936 & .000 \\
\hline & 1 & 1.119 & 13870.000 & .240 & 8.071 & .000 \\
\hline
\end{tabular}

As we can observe, the Sig coefficient is equal to 0.000 , and less than $5 \%$ of the area under $\mathrm{H}_{1}$ is confirmed by the linear relationship. The $\mathrm{F}$ statistic is equal to 65.137 , and at this level, regression is significant. In the table of coefficients, it can be observed that the $t$ statistic is equal to 8.071. Therefore, a relationship between inflation and net profit does exist. The model can be estimated as follows:

$N P R=-1700.368+1.11 i$

Results indicate there is a direct relationship between inflation and net income. Since the $\beta$ coefficient (1.11) is highly significant, it can be concluded that net income can hedge against present inflation.

In the second and third test, the $\beta$ coefficient is positive, but low. No significant correlation exists between these two variables in the past and future period.

\subsection{Results of $\mathrm{H}_{2}$ test}

The next hypothesis is associated with the relationship between GPR and interest rate and they are summarized on Table 4, Table 5 and Table 6.

Table 4

Model Summary

\begin{tabular}{ccccc}
\hline Model & $\mathrm{R}$ & $\mathrm{R}$ Square & Adjusted R Square & Std. Error of the Estimate \\
\hline 1 & $.240 \mathrm{a}$ & .058 & .057 & 1659.38835 \\
\hline a. predictors: (constant), inflation & & &
\end{tabular}

\section{Table 5}

The results of ANOVA ${ }^{b}$

\begin{tabular}{ccccccc}
\hline & Model & Sum of Squares & df & Mean Square & F & Sig. \\
\hline \multirow{2}{*}{1} & Regression & 179458 & 1 & 1794.58 & 65.168 & $.000 \mathrm{a}$ \\
& Residual & 293809 & 1067 & 2753.56968 & & \\
& Total & 3.11589 & 1068 & & & \\
\hline
\end{tabular}




\section{Table 6}

The results of regression analysis (Dependent Variable: GPR)

\begin{tabular}{|c|c|c|c|c|c|}
\hline \multirow[t]{2}{*}{ Model } & \multicolumn{2}{|c|}{ Unstandardized Coefficients } & $\begin{array}{c}\text { Standardized } \\
\text { Coefficients }\end{array}$ & \multirow[t]{2}{*}{$\mathrm{t}$} & \multirow[t]{2}{*}{ Sig. } \\
\hline & B & Std. Error & Beta & & \\
\hline \multirow{2}{*}{1} & -1698.508 & 214.263 & & -7.936 & .000 \\
\hline & 1.11968 & 1.3870 & 0.240 & 8.073 & .000 \\
\hline
\end{tabular}

As evident, the Sig coefficient is equal to 0.000 , and less than $5 \%$ of the area under $\mathrm{H}_{2}$ is confirmed by the linear relationship. The $\mathrm{F}$ statistic is equal to 65.168 , and at this level, regression is significant. In the table of coefficients, it can be observed that the $t$ statistic is equal to 8.073. Therefore, a relationship exists between inflation and gross profit. The model can be estimated as follows:

$G P R=-1698.508+1.12$

Results indicate there is a direct relationship between inflation and gross profit. Since the $\beta$ coefficient is highly significant, it can be concluded that gross profit can hedge against present inflation.

In the second and third test, the $\beta$ coefficient is positive, but low. No significant correlation exists between these two variables in past and future periods

\subsection{Results of $\mathrm{H}_{3}$ test}

We now examine the third hypothesis of this survey on relationship between ROA and interest rate and the results are summarized on Tables 7-9

Table 7

Model Summary

\begin{tabular}{lcccc}
\hline Model & $\mathrm{R}$ & $\mathrm{R}$ Square & Adjusted R Square & Std. Error of the Estimate \\
\hline 1 & $.73 \mathrm{a}$ & .005 & .004 & 14.03863 \\
\hline a. predictors: (constant), inflation & & &
\end{tabular}

Table 8

The results of ANOVA ${ }^{\mathrm{b}}$

\begin{tabular}{llccccc}
\hline Model & & Sum of Squares & df & Mean Square & F & Sig. \\
\hline \multirow{3}{*}{1} & Regression & 1123.718 & 1 & 1123.718 & 5.702 & $.117 \mathrm{a}$ \\
\cline { 2 - 7 } & Residual & 210287.578 & 1067 & 197.083 & & \\
\hline
\end{tabular}

a. Predictors: (Constant), inflation

b. Dependent Variable: ROA

Table 9

The results of regression analysis (Dependent Variable: ROA)

\begin{tabular}{cccccc}
\hline Model & \multicolumn{2}{c}{$\begin{array}{l}\text { Unstandardized } \\
\text { Coefficients }\end{array}$} & $\begin{array}{c}\text { Standardized } \\
\text { Coefficients }\end{array}$ & & \\
\cline { 2 - 4 } & $\mathrm{B}$ & Std. Error & Beta & t & Sig. \\
\hline (Constant) & 8876 & 495 & & 17.921 & .000 \\
\hline 1 & 0.038 & 0.016 & 0.073 & 2.388 & .017 \\
\hline
\end{tabular}

Significant level in the ANOVA table is less than 5\%, and the F statistic is critical; therefore, linearity assumption is confirmed. In the table of coefficients, it can be seen that the $t$ statistic is equal to 82.388. Therefore, there is a relationship between inflation and ROA, and the model can be estimated as follows, 
$R O A=8876+0.0381$

In the first test, the relationship between current inflation and the return on assets is positive but low. The results indicate that ROA is not a good hedge against inflation. In the second test, the beta coefficient is negative. Thus, there was no correlation between ROA and inflation in the past period. In the third test, the beta coefficient is low; therefore, there was no correlation between ROA and inflation in future periods.

\subsection{Results of $\mathrm{H}_{4}$ test}

Finally, we present details of our survey on testing the last hypothesis of this survey and they are summarized on Tables 10-12.

Table 10

Model Summary

\begin{tabular}{ccccc}
\hline Model & & & Std. Error of the \\
& $\mathrm{R}$ & $\mathrm{R}$ Square & Adjusted R Square & Estimate \\
\hline 1 & $.68 \mathrm{a}$ & .005 & .004 & 126.70824 \\
\hline a. predictors: (constant), inflation & & &
\end{tabular}

Table 11

The results of ANOVA ${ }^{\mathrm{b}}$

\begin{tabular}{llccccc}
\hline Model & & Sum of Squares & df & Mean Square & F & Sig. \\
\hline 1 & Regression & 78915.363 & 1 & 78915.363 & 4.915 & $.027 \mathrm{a}$ \\
& Residual & 17130661.55 & 1067 & 16054.978 & & \\
\cline { 2 - 7 } & Total & 1729576.917 & 1068 & & & \\
\hline
\end{tabular}

a. Predictors: (Constant), inflation

b. Dependent Variable: ROE

\section{Table 12}

The results of regression analysis (Dependent Variable: ROE)

\begin{tabular}{|c|c|c|c|c|c|}
\hline \multirow[t]{2}{*}{ Model } & \multicolumn{2}{|c|}{ Unstandardized Coefficients } & \multicolumn{3}{|c|}{ Standardized Coefficients } \\
\hline & $\mathrm{B}$ & Std. Error & Beta & $\mathrm{t}$ & Sig. \\
\hline (Constant) & -3305 & 1681.9 & & -1.97 & .844 \\
\hline 1 & 0.2409 & 1.087 & 0.068 & 2.217 & .027 \\
\hline
\end{tabular}

Significant level in the ANOVA table is less than 5\%, and the $\mathrm{F}$ statistic is critical. Therefore, linearity assumption is confirmed. In the table of coefficients, it can be seen that the $t$ statistic is equal to 2.217. Therefore, there is a relationship between inflation and ROE, and the model can be estimated as follows:

$R O E=-3305+0.240 i$

In the first test, the relationship between current inflation and return on assets was positive, but the correlation was weak. In the second and the third tests, the beta coefficient was low; thus, there was no correlation between ROE and inflation in the past and future periods.

\section{Discussion and Conclusions}

The current study tries to examine the relationship between inflation rate and profitability ratios in the top 36 companies in the Tehran Stock Exchange (TSE). The study has been accomplished over the period 2005-2010 by using linear regression methods. The test results show that there was a significant correlation between inflation rate and profitability ratio, but no significant correlation between the two variables in past and future periods. From among the four hypotheses considered, the 
first and second hypotheses (GPR and NPR) compared with the third and fourth (ROA and ROE) hypotheses are correlated with current inflation.

In this research, we also attempted to remove the impact of inflation from investment decisions so investments can be made with greater confidence. Studies have shown that investors should consider inflation rates in their investment decisions, because the inflation rate affects profitability ratio.

\section{References}

AL-Rjoub, S. (2005). The Adjustments of stock price to information about inflation: Evidence from MENA countries. Applied Economics Letters, 12, 871-879.

Anari, A., \& Kolari, J. (2001). Stock prices and inflation. The Journal of Financial Research, 4, 587602.

Boucher, C. (2004). Stock prices, inflation and stock returns predictability. CEPN University of Paris-Nord, Version 16.

Boudoukh, J., \& Richardson, M. (1993). Stock returns \& inflation: A long horizon perspective. American Economic Review, 83, 1335-1346.

Choudhry, T. (1999). Inflation and rates of return on stocks : evidence from high inflation countries. Journal of International Financial Markets, Institution \& Money 11, 75-96.

Ely, D., \& Robinson, K. J. (1997). Are stocks a hedge against inflation? International evidence using a long run approach. Journal of International Money and Finance, 16, 141-167.

Faiza, S., Laraib, Z., \& Bisma, R. (2013). Long run relationship between inflation and stock return: evidence from Pakistan. Social sciences and Humanities, 4(2), 407-415.

Fisher, I. (1930). The theory of interest. Macmillan, New York.

Johansen, S. (1998). Statistical analysis of Cointegration Vectors. Journal of Economic Dynamics and Control, 12, 231-254.

Luintel, K., \& Paudyal, K. (2006). Are common stocks a hedge against inflation ?. Journal of Financial Research, 29,1-19.http://dx.doi.org/10.111/j.1475.2006.00163.x

Nwakanma, P. C., \& Ajibola, A. (2013). Inflation Dynamics and Returns on Equity: The Nigerian Experience. International Journal of Economics and Finance, 5(2), p164.

Rano, S. U., \& Bayero, A. (2010). Does inflation has an impact on stock returns and volatility? Evidence from Nigeria and Ghana. 1-17.

Ray, S. (2012). Inflation and stock price behavior in selected Asian Economics : An Econometric snapshot. Advances in Asian Science (AASS), 2(1), 387-397.

Spyrou, S. I. (2001). Stock returns and inflation: Evidence from an Emerging market. Applied Economics Letter, 8, 447-450.

Wei, Ch. (2010). Inflation and stock price: No Illusion. Journal of Money, Credit and Banking, 42(23), 325-345. 